\section{Callus Growth Inhibitors from Persimmon Calyx}

\author{
Hideo HaYashi, Koichi KoshimizU \\ Tadashi AsAHIRA* \\ and Satoshi MatsubarA** \\ Department of Food Science and Technology, \\ * Laboratory of Olericulture and Floriculture, \\ Kyoto University, Kyoto 606, Japan \\ ** Laboratory of Applied Biology, \\ Kyoto Prefectural University, Shimogamo, \\ Kyoto 606, Japan
}

Received September 30, 1977

Among various fruits, persimmon has been known to contain the high level of cytokinins. ${ }^{13}$ The cytokinin activity in the fruit is found to increase markedly until 30 days after anthesis. ${ }^{2)}$ The activity in the calyx was much lower than in the fruit and diminished quickly after flowering. ${ }^{23}$ Nakamura $^{3)}$ reported that removal of calyx lobes from the fruit inhibited the fruit enlargement and increased the rate of fruits dropping. These phenomena suggested to us that calyx plays an important role in the physiological process of fruit development. In our search for regulating factors on callus growth from persimmon fruits, extracts of the calyces were found to have callus growth inhibiting activity. In this paper we wish to report the isolation and the identification of the active constituents, along with the biological activity on the growth of tobacco callus.

The isolation of the constituents was guided by bioassay using callus culture of tobacco (Nicotiana tabacum var. Wisconsin No. 38). ${ }^{4}$ The cultures were kept in the dark at $28^{\circ} \mathrm{C}$. After a 4 week growth period, the tissues were harvested and weighed.

Fruits $(170 \mathrm{~g})$ of Japanese persimmon (Diospyrous kaki L., cv. Fuyu) and the calyces $(95 \mathrm{~g})$ were collected about three weeks after anthesis. Each part was extracted with methanol. After removal of methanol, the aqueous concentrate, adjusted to $\mathrm{pH} 3$ with $6 \mathrm{~N} \mathrm{HCl}$, was extracted with ethyl acetate. The ethyl acetate phase was concentrated to give a residue, designated fraction $A$ (fruits; $90 \mathrm{mg}$, calyces; $930 \mathrm{mg}$ ). The aqueous phase was adjusted to $\mathrm{pH} 8$ with $6 \mathrm{~N} \mathrm{NH}_{4} \mathrm{OH}$ and partitioned with $n$-butanol. The $n$-butanol phase was concentrated to give fraction $\mathrm{B}$ (fruits; $170 \mathrm{mg}$, calyces; $640 \mathrm{mg}$ ) and the remaining aqueous phase to give fraction $\mathrm{C}$ (fruits; $3.7 \mathrm{~g}$, calyces; $2.5 \mathrm{~g}$ ).

Table I. Effects of the Extracts from Persimmon Fruit and Calyx on the Growth of Tobacco Callus

\begin{tabular}{lcc}
\hline \multicolumn{1}{c}{$\begin{array}{c}\text { Additives to the } \\
\text { basal medium }\end{array}$} & & \multicolumn{2}{c}{ Fresh weight (mg) of callus } \\
\cline { 2 - 3 } & Fruit & Calyx \\
\hline $\begin{array}{l}\text { Fraction A } \\
\text { (ethyl acetate soluble) }\end{array}$ & 199 & 95 \\
$\begin{array}{l}\text { Fraction B } \\
\text { ( } n \text {-butanol soluble) }\end{array}$ & 1357 & 1125 \\
$\begin{array}{l}\text { Fraction C } \\
\text { (water soluble) }\end{array}$ & 2416 & 215 \\
$\begin{array}{l}\text { Fraction A } \\
+0.03 \mathrm{mg} / \text { liter kinetin }\end{array}$ & 1110 & 237 \\
$\begin{array}{l}\text { Fraction B } \\
+0.03 \mathrm{mg} / \text { liter kinetin }\end{array}$ & 2235 & 2146 \\
$\begin{array}{l}\text { Fraction C } \\
+0.03 \mathrm{mg} / \text { liter kinetin }\end{array}$ & 2414 \\
$\begin{array}{l}\text { None } \\
0.03 \mathrm{mg} / \text { liter kinetin }\end{array}$ & 223 \\
\hline $\begin{array}{l}\text { Concentration of fractions A, B and C: } 50 \mathrm{~g} \text { of } \\
\text { fresh fruits and calyces per liter of the cultural }\end{array}$ \\
$\quad$ medium.
\end{tabular}

Effects of the above fractions on the callus growth are shown in Table I. Fractions B and $\mathrm{C}$ from the fruits exhibit growth promoting activity and the fraction $\mathrm{A}$ has no appreciable effects on the callus growth. In the case of the calyces, only fraction B promotes the growth. Fractions $\mathrm{A}$ and $\mathrm{C}$ elicit no stimulation of the callus growth in the presence and absence of kinetin. These data suggested that fractions $\mathrm{A}$ and $\mathrm{C}$ from the calyces contained growth inhibitors.

Fraction A (93 g) obtained by large scale extraction of the calyces $(9.5 \mathrm{~kg})$ was chromatographed on a column of silicic acid, eluting with benzene followed by increasing portions of ethyl acetate. The growth inhibitory activity was found in $20 \%$ and $30 \%$ ethyl acetate eluates. Further purification of the active fractions afforded two inhibitory factors 1 
(230 mg) and $2(30 \mathrm{mg})$ in crystalline form, respectively.

Factor 1, purple plates from hexane-acetone, mp $227 \sim 229^{\circ} \mathrm{C}$ (lit. $\left.{ }^{5}\right), 228^{\circ} \mathrm{C}$ ), $[\alpha]_{\mathrm{D}}^{]^{2}}+16.8^{\circ}(c=$ $\left.0.17, \mathrm{CHCl}_{3}\right), \mathrm{C}_{36} \mathrm{H}_{38} \mathrm{~N}_{4} \mathrm{O}_{5}\left(\mathrm{M}^{+}, 606\right)$, showed $\lambda_{\mathrm{max}}^{\mathrm{CHCl}_{3}} \mathrm{~nm}(\varepsilon): 414(91,500), 507(10,600), 538$ $(10,200), 610(8700)$ and $668(47,000)$, indicating that 1 was a dihydroporphyrin. The PMR signals of 1 were assignable to all protons of methyl pheophorbide a. The identity was confirmed by comparing the VIS, IR and PMR spectra with an authentic sample.

Factor 2, dark green lustrous plates from dichloromethane-methanol, $\mathrm{mp} 250 \sim 256^{\circ} \mathrm{C}$ (dec.) (lit., ${ }^{5)} 264 \sim 267^{\circ} \mathrm{C}$ ), $[\alpha]_{\mathrm{D}}^{32}+20.4^{\circ} \quad(c=$ $\left.0.15, \mathrm{CHCl}_{3}\right), \mathrm{C}_{36} \mathrm{H}_{36} \mathrm{~N}_{4} \mathrm{O}_{6}\left(\mathrm{M}^{+}, 620\right)$, showed $\lambda_{\max }^{\mathrm{CHCl}_{3}} \mathrm{~nm}(\varepsilon): \quad 440(176,000), 527 \quad(12,100)$, $600(9000)$ and $655(35,300)$, indicating that 2 was an analogous compound of 1 . The PMR spectrum of 2 showed the same features of signals, except that one of the three signals assigned to vinyl methyls of factor 1 was replaced by the signal due to a formyl proton. Thus, 2 was identified as methyl pheophorbide b.

Table II. Effects of Factors 1 and 2 (Methyl PHeOPHORBIDES a AND b) ON THE GROWTH of Tobacco Callus

\begin{tabular}{cccccc}
\hline \multirow{2}{*}{$\begin{array}{c}\text { Concent- } \\
\text { ration } \\
\text { mg/liter }\end{array}$} & \multicolumn{2}{c}{ Factor 1 } & & \multicolumn{2}{c}{ Factor 2 } \\
\cline { 2 - 3 } \cline { 5 - 6 } & Expt. 1 & Expt. 2 & & Expt. 1 & Expt. 2 \\
\hline 0 & 33 & 1827 & & 33 & 1827 \\
0.1 & 34 & 1778 & & 16 & 1632 \\
1 & 26 & 1717 & & 29 & 1464 \\
10 & 10 & 961 & & 31 & 1039 \\
\hline
\end{tabular}

Expt. 1: in the absence of kinetin.

Expt. 2: in the presence of $0.06 \mathrm{mg} /$ liter kinetin.

The effects of factors $\mathbf{1}$ and $\mathbf{2}$ on the tobacco callus growth are shown in Table II. In the absence of kinetin, neither 1 nor 2 exhibit cytokinin activity in the range of concentration tested. In the presence of $0.06 \mathrm{mg} /$ liter kinetin, both 1 and 2 reduce the callus growth by about $45 \%$ at a concentration of $10 \mathrm{mg} / \mathrm{liter}$.

Since the phytyl side chain of chlorophylls is replaced with methyl in methanol by the action of chlorophyllase during the cource of extraction, ${ }^{6}$ the possibility remained that 1 and 2 might be artifacts derived from chlorophylls. In the methanol-free system, however, $\mathbf{1}$ and $\mathbf{2}$ were obtained from the calyces in the same yield. Another possibility that 1 and $\mathbf{2}$ might be artifacts arising from corresponding chlorophyllides can not be excluded, due to elimination of magnesium from chlorophyllides under slightly acidic condition. ${ }^{6)}$

Cytokinins retard the senescence of detached leaves of many herbaceous plants ${ }^{7}$ and the leaf senescence in intact bean plants. ${ }^{8}$ ) In addition to these effects, cytokinins are necessary for chloroplast differentiation ${ }^{93}$ and enhance chlorophyll production. ${ }^{10)}$ However, the inhibitory effect of methyl pheophorbides a and $b$ on cytokinin-dependent tobacco callus is, so far as we know, herein reported for the first time.

The physiological role of methyl pheophorbides $\mathrm{a}$ and $\mathrm{b}$ in the fruit development and the biological effect of the other chlorophyllrelated compounds on the callus growth are being studied.

Acknowledgement. The authors wish to express their sincere thanks to Dr. A. Kato, Faculty of Pharmaceutical Science, Kyoto University, for measuring mass spectra. We are also grateful to Associate Prof. Y. Furukawa, Faculty of Agriculture, Kyoto University, for kindly supplying persimmon fruits. This work was supported in part by a grant for the scientific research from the Ministry of Education.

\section{REFERENCES}

1) S. Matsubara, M. Kosugi and R. Nakahira, Sci. Rep. Kyoto Pref. Univ. (Nat. Sci., Liv. Sci. and Welf. Sci.), 21(A), 7 (1970).

2) Y. Sobajima, M. Ishida, A. Inaba and H. Horiguchi, J. Japan Soc. Hort. Sci, 43, 224 (1974).

3) M. Nakamura, Res. Bull. Fac. Agr. Gifu Univ., 23, 1 (1967).

4) F. M. Linsmaier and F. Skoog, Physiol. Plant., 18, 100 (1965).

5) G. W. Kenner, S. W. McCombie and K. M. Smith, J. Chem. Soc. Perk. I, 1973, 2517.

6) O. T. G. Jones, "Phytochemistry," Vol. I, ed. by L. P. Miller, Van Nostrand Reinhold Co., New York, N. Y., 1973, pp. $75 \sim 111$.

7) D. S. Letham, Ann. Rev. Plant Physiol., 18, 349 (1967).

8) R. A. Fletcher, Planta, 89, 1 (1969).

9) D. A. Stetler and W. M. Laetsch, Science, 149, 1387 (1965).

10) R. A. Fletcher and D. McCullagh, Can. J. Bot., 49, 2197 (1971). 